\title{
Drama as a Mode of Communication in the Ancient Greek World
}

\author{
Sepali Bamunusinghe \\ Lecturer \\ Department of Accounting \\ University of Sri Jayewardenepura \\ sepali20@gmail.com
}

\begin{abstract}
In the ancient Greek world, drama was a part of their lives, something intimate, frequent and inseparable. It was not the individual choice that took the mass to the Greek theatre, but they were a part of this process of dramas as a nation, which came in the guise of rituals of festivals, held in honour of god Dionysus. Drama and drama festivals were facilitated with state recognition and were sponsored by the rulers of the city-states, encouraging the citizens to participate in them. Massive theatre structures were constructed, providing seating capacity for thousands. Within such appealing circumstances, Greek drama has evolved through time, gifting outstanding dramatists and drama compositions to the world of aesthetics. Greeks being a nation whose lives were embedded in a performance culture, drama was the most effective and intimate to be utilized as a mode of communication, during such an ancient period where there were no other modes of communication like in the world of today.
\end{abstract}

Key Words: Communication, Performance Culture, Ancient Greek World

\section{Introduction}

The beginning of Greek drama goes back to thousands of years. It was a gift not only to the Western world, but also to the whole world of arts. Greek drama was a mode of art which had such an impact over the Greek life style and Greek culture and its popularity among the people was irresistible. During such an ancient time, communication modes being so limited, it was drama that played an effective role as a mode of communication to the citizens of the ancient Greek world. While the Greek tragedians attempted to touch on the untouched deep human emotions and concepts with the appropriate use of the subject matters and tragic characters, even the comic writers were successful enough to convey the bitter truths about humanity and current issues as bitter pills coated with sugar of laughter. The public who roared with laughter within the theater, on their way home, pondered over their own laughter and that was the wonderful space created by the comedians for the mass to understand the bitter truths which were discussed upon the stage. Although the beginning of drama was the religious rituals, once it was established as an accepted mode of art in Greek culture, the dramatists were not reluctant to go into philosophical aspects of humanity and world which they observed around them through their drama compositions. Human existence, nature of the world, destiny or fate which could not be altered even by the divine intervention and tragic sense of humanity which prevails within the human soul are such themes that the Greek dramatists handled. 


\section{Discussion}

History of Greek drama goes back to centuries of years while most of the historians believe that it began long before $700 \mathrm{BC}$ and that foundation of western drama was laid upon the Hellenic soil. Greek peninsula is situated in the Aegean Sea which is sprinkled with a number of small islands. The season of summer is hot in Greece but the constant winds which are blowing across the sea during sunset, soothes the temperature. Since rains as well as snowing are rare in Greece, it is clear why the Greeks preferred a life outof-house rather than restricting themselves within the domestic limits. Thus not only their drama festivals, athletic competitions and religious festivals but their political meetings and philosophical discussions were also held outdoors. Even during such an ancient era, it is surprising how the Greeks have found the laws of ethics, ruling systems such as oligarchies, monarchies and democracies and also the mastery in sculpture, architecture and pottery while laying the foundation for modern science and philosophic theories. Therefore it is clear that it was within such a developed civilization that we meet these Greek dramatists and their compositions, themes they have touched upon, the contemporary subject matters they have discussed and the dark human emotions they have brought out in to light.

As history unveils, not only in the city-states of Greece but also in the foreign Greek colonies, there have been developed dramas but unfortunately only a limited number of them remain at the moment and in amount, it is probably one tenth of the dramas which have been composed and produced by the ancient Greeks. Although the term 'Greek Drama' indicates dramas sprung up from the whole Greek world, it should be realized that the dramas that we read today are the dramas which were composed and produced in the Athenian world. Most of the literary compositions of the $5^{\text {th }}$ and $4^{\text {th }}$ centuries are dramas and that was the golden period of Greek drama and it is clear that although it was a time of conflict and chaos in Athens, mainly due to the Persian Wars, it has not disturbed or interrupted dramatic activities. It is still an unanswered question whether during that particular era all the other literary compositions were on hold or whether they were not powerful enough to challenge the great drama compositions that are left with us at present. An admirable support and encouragement was rendered by the Athenian government for the enhancement of Greek drama and the aesthetic activities in the citystate and out of the rulers of Athens, Peisistratus, Hipparchus, Themistocles and Pericles are outstanding in this regard. Therefore within such appealing circumstances, Greek Dramatists were able to communicate well with the public through their dramatic productions.

The emphatic role played by Greek drama in Greek civilization is immense with regard to its culture, social elements, religion and day today life. There has been a performance culture in Athens and the areas of politics, law, religion, athletics, festivals, music and poetry shared with the theatre an essentially public and performative nature (Rehm, 1992). Especially Greek tragic theater was such a kind of performance which had absorbed its strengths and essence from public occasions that surrounded it. The important aspects of day today life such as various rites performed at weddings, funerals and such occasions were carried out in a theatrical fashion. In every aspect of Greek 
culture, there were the notions of a performing nature, therefore 'drama' was a very intimate mode for the Greeks and this could be one reason for drama to be so connected with Greek life. In other words, performance culture or drama was not a new thing to the Greeks but something which was embedded in the life of the Greeks and the most intimate mode which could be utilized as the medium of communication.

Athenian society as a whole was inspired with a sense of event and the things were done in a theatrical fashion. A basic ritual pattern distinguished most festival worship and the form it took included many outstanding theatrical elements. A procession made its way to the temple where the cult-image of the deity was placed and this parade included priests wearing sacral robes, underlings who carried various ritual objects, attendants who led the beasts to be sacrificed, common folk who marched or simply watched as the others passed by (Rehm, 1992). On the Parthenon frieze, the grand processions of Panathenia are depicted in detail, which unveil the richness and elegance of those parades. Then the crowd of the procession assembled before the altar of the temple and witnessed the performance of the sacrifice itself. At the altar steps, the priest uttered a series of prayers and it was then the dramatic moment arrived. When the first animal was struck, the women raised the ritual cry and the smoke of burnt flesh rose to the heavens. After the sacrifice, the inedible parts of the animal were dedicated and burnt to the gods and the rest was cooked and distributed among the crowds. After the feast, the other events of the festival proceeded and these included performances organized as contests. There were athletic events, instrumental competitions on the kitharode (Lyre) and aulos (a reed instrument comparable to a clarinet), solo songs accompanied by the lyre and also choral singing. Although they were performances which were fulfilled as rituals to the divinity, the performers always attempted to attract the crowd who watch them as the audience and this was certainly the case at the City Dionysia, the main festival where comedies and tragedies were performed (Rehm, 1992). Apart from the festivals held in Athens, great pan-Hellenic (all-Greek) festivals were celebrated at Olympia, Nemea and Isthmia which were athletic competitions and contests in poetry and music were held at Delphi and Athens sent an ambassador to each of these festivals, and the Athenian citizens participated in those competitions. It is this particular performative culture, which modeled the Greeks as a nation who perceived drama as a notion which is rooted in them. For them, the dramas were a part of them and not something they watched during their leisure. Therefore, drama became a better mode of communication, where the dramatists of the time got the opportunity to convey the messages and morals to the citizens, through their drama productions, where everything around them took place in a theatrical fashion.

According to Storey and Allan (2005), in classical Athens plays were performed in a public setting, in a theater placed next to the shrine of a god and as part of the worship of that god, in broad daylight where spectators would be conscious of far more than the performance unfolding below - of the city and country around them and of their very existence as spectators. Drama was a part of the worship of the god and it is the very existence of the audience that they have perceived upon stage in dramatic guises. In Athens, every dramatic performance was a part of a religious festival held either by state or by a local community and evidence strongly suggests that this was always and 
everywhere the normal pattern and it does prove that dramatic performances were public and civic events (Sommerstein, 2004).

Although women were not allowed in the drinking parties of men unless present as musicians, dancers or prostitutes, women had sung and told stories when they worked at the loom and their participation in various religious cults were also included songs and dances of a more sober nature (Rehm, 1992). It is a factor which should not be forgotten that the Geek theatre was open not only for males but also for women, non- Athenians and also for slaves. According to Rehm (1992), there are references to, and enactments of, these ritual and artistic practices in every tragedy, as if the overtly performative genre of theater acknowledged its debt to the other manifestations of Athenian performance culture. Throughout Greek culture, it could be identified, the wonderful support and the encouragement, rendered by the state for the citizens in participating these drama festivals. Because although the drama festivals were a part of worship in honour of Dionysus, it must be remembered that they were also state occasions run by the public officials of Athens, a part of the communal life of the city or polis. (Storey and Allan, 2005).

It is interesting to observe the performance culture which is visible in carrying out the meetings of the Assembly of Athens which is a legislative body that consisted of freeborn Athenian male citizens over 18 years of age. When the members of the Assembly gathered on the hill Pynx for their meetings through the power of the spoken word and by various appeals to reason, emotion and morality, the Assembly speakers swayed the citizen body, much like actors in a large outdoor theater (Rehm, 1992). Everyone who was present there had the freedom to speak, although the audience was more than six thousand. The relationship which could be observed between the speaker and their audience in the Assembly has mirrored the relationship between actors and spectators at the great theater of Dionysus (Rehm, 1992). Even in the smaller political forums, such as the Council which is a body of 500 citizens, who set the agenda for the Assembly, had this performative nature. As Rehm (1992) describes, at the end of the fifth century, when the Council chamber was rebuilt, the seating banks were set around the speaker's platform on the model of the cavea surrounding the orchestra in the Athenian theater. Not only in the legislative bodies of the Athenians but also Greek tragic performance was found in the Athenian law courts as well. In Thucydides' 'History', it is visible how the historian is screening the articulacy and power of political speeches made by the opposing speakers in various debates presented in the book which carries all the energy and imaginative quality of a dramatic scene to the audience who were listening. Therefore it is visible that in every aspect of Greek culture, this performative element was noticeable and such instances really prove that drama could have been the best mode of communication for the Greeks since the dramatic notions were not new to them at all.

There were more than hundred days in the calendar year of the Athenian state, which were devoted and organized around religious cults that were endorsed by the 'polis' (city). But it must be remembered that unlike the political forums of the city, most civic festivals were open to everyone - men, women, slaves, children, resident aliens, visiting foreigners (Rehm, 1992). There had been exceptions where males were excluded from the women festivals which were associated with Demeter, but in general, all the citizens 
gathered together for the various events. When discussing about the solo songs, choral singing and dancing events performed by the Greeks, it is clear that although the contestants officially offered their various performances to the divinity, their efforts were directed primarily to the tastes and interests of the people who gathered as celebrants to watch and listen, to judge and reward (Rehm, 1992). These particular words prove that those great drama festivals must have been the wonderful outcome of those efforts by those performers.

Discussing further about the performance culture in Athens, it is clear that the rituals connected with weddings and funerals have played a central role in the life of the Greek family and as such, constitute a recurring motif in Greek tragedy. No ritual was considered as a single event, but they have been conceived as an ongoing series of performed activities and these have offered the playwrights a variety of possible points of reference. When considering about the rituals of the Greek weddings, this performative nature is visible. On the wedding day, the Athenian bride and groom were given a ritual bath separately and then they were dressed in white with a crown or garland to mark this ceremonial occasion. The evening of the wedding day began with a banquet offered by the bride's father. The gathered company danced and sang wedding hymns and then in a procession, the bride was ushered to her new home by the bride groom. This journey was made by horse or mule cart, accompanied by torch-bearers and friends who played music and sang. The groom's parents welcomed the new couple and during the night, the crowd who accompanied the procession sang epithalamia (songs 'outside the marriage chamber') and in the morning, the songs awakened the couple who received gifts in a ceremony that led up to a final wedding banquet. Such references to these rites are visible in many tragedies and Rehm (1992) mentions that "from the nuptial bath that Polyxena will never have in Hecuba to the wedding procession Admetus remembers in Alcestis, from the wedding hymn that Sophocles' Antigone sings en route to her 'burial', to the poisoned wedding gifts that convert Glauke into her own nuptial torch in Medea" and these are such indications to wedding rites which are visible in the Greek world.

Funeral rites also constituted a performance for and about the dead with regard to the ritual spectrum and according to Rehm (1992), the corpse was anointed, dressed, crowned and adorned with flowers by the female members of the family. Then the body was laid out in the courtyard and the mourners paid their respects while the women wailed and lamented. When it was the time for the burial, the funeral party dressed in black and the men led the funeral cortege, which was followed by women reciting the ritual lament, accompanied by professional musicians and dirge-singers. The funeral rituals were organized and performed by the family and friends of the deceased and after the cremation, a final funeral hymn was performed, offerings were poured and the mourners departed. In the evening a banquet was held and the funeral party delivered eulogies for the deceased and sang funeral hymns. "The lamentations and threnodies that resound through Aeschylus' Persians, the focus on burial in Sophocles' Ajax and Antigone, the procession of corpses in Euripides' Suppliant Women" are such examples that Rehm (1992) brings out with regard to funeral rites of the Greeks and the performance culture he has identified in them and he further mentions that in fact, aspects 
of the funeral ritual occur so frequently in tragedy that scholars once thought the earliest drama sprang from laments at the grave-site.

The contests for reciting the great epic poems of Homer, the Iliad and the Odyssey have also played an important role in the development of Greek tragedy. Although unofficial performances of Homer went back many years, official competition among rhapsodes was included in the Panathenaic festival sometime between 566 and 514 BC (Rehm, 1992). When compared with the other pre-tragic contests, epic recitation was not based on music, spectacle or lyric poetry, but on the semi dramatic presentation of a complex narrative. It is surprising to witness the highly theatrical quality in those epics and the scenes which are more like written for the stage, although they were composed long before the first tragedy in Greek history and also the oral and aural qualities of Homeric poems reminds us of their close connection with performance. In addition to the epic's formal influence, it would be hard to exaggerate the importance of the Homeric poems on the spirit, sensibility and ethos that gave rise to Greek tragedy (Rehm, 1992). It is clear that the Iliad and Odyssey provide the prototypes for plots and character types who appear in Greek tragedy and comedy and according Rehm (1992), the Iliadic Hector, Achilles, Patroclus, Priam, Hecuba and Andromache are the ancestors of the great heroes in Greek tragedy and the clear inventiveness of Odysseus in the Odyssey is visible in the comic heroes of Aristophanes. Thus these Homeric poems have gifted the dramatists, the power of words to animate the dramatic imaginations of the audience, the characters whom they perceived in their inward eye and after years, it was them who became alive in Greek drama as the heroes and heroines.

Greek drama, especially Greek tragedy, is eminently emotional and entertaining. In a world of small cinemas and contained theaters, we cannot realize what the experience of the ancient outdoor civic theater was like (Storey and Allan, 2005). According to Aristotle, the "end" of tragedy is to elicit pity and fear and to achieve a katharsis of these emotions, and an audience of some 15,000 people must have responded to a particularly effective drama (be it tragedy or comedy) with a collective and emotional response. One of the results of the worship of Dionysus was the achieving of ecstasy (in Greek, ekstasis or "standing out"), and some might assume that the aesthetic experience of attending the theater, suspending disbelief, and becoming involved in the sufferings of another was in some sense an ekstasis". It is in such a way that Storey and Allan (2005) discuss about the impact of Greek drama on Greek life.

Sommerstein (2004) compares and contrats the modern drama with Greek Drama where he says that modern dramatic performances are of two kinds. In one variety (film, video, television) the spectators are separated in space and time from the performers, and often also from each other; they are basically inactive consumers of a prepackaged product. Even in the other (live theatre in its various forms), where performers and spectators are in one place, the audience is normally just a crowd of ticket-buying individuals. Sometimes, to be sure, a production is closely associated with a particular sub community (e.g. a school, a church, a village) and involves all or most of its members either as performers, ancillaries or spectators; but theatrical events of that type are not normally considered to be of central importance either to the art of theatre or to society in general. But in classical Athens, the dramatic performances were essentially and in principle, 
events for the whole community. This indeed was one reason, why they formed part of religious festivals where the Greeks found them so connected with their real life, due to the performance culture which was in progress during that time. As Sommerstein (2004) denotes, one should not look at Greek drama with the perceptions of modern drama. For the modern world, drama is a means of spending leisure or an attempt to break the boring daily routine. But in the Greek world, it was a part of their life, something intimate and so connected with Greek life.

The main fence between ourselves and Greek drama is that we approach it with the wrong prospect. To us, drama is something which is going around us most of the time and we can take it or leave it by switching on the television or going out to the theatre or cinema. But for the Greeks of that time, drama was not such a kind of entertainment but a part of celebrations held for the god Dionysus or in other words they would throng the theatre on a number of successive days and be part of a majestic civic ceremony (France, 1993).

Being a part of the modern audience, even we are used to modern drama as they deal with real life human situations and stick close to real life characters whom we recognise in the world outside. According to France, (1993) the first and most obvious objection to our being moved by classical Greek tragedies is that they do not deal with real people. But the objective of this study is not to understand the role played by Greek drama in Greek cuture today, but during those ancient days and for that our attention should be paid to the mentality of the Greeks who belonged to that ancient era. They are plays that deal with mythical larger-than-life characters whose actions are controlled by the gods. But what we must remember is that although this involvement of gods and human affairs is a new notion to the modern world, it was not so for the ancient Greeks.

Chester G. Starr, discusses widely on the role played by Greek drama in Greek culture and according to him "the $5^{\text {th }}$ century view of man is nowhere better displayed than in the Attic tragedies. Again and again a great man or woman stepped forth upon the stage, only to be stripped of pride and often to die violently in ruin. The vehicle for the ruin was a man's own flaws, for man was free; and yet behind all lay the immortal gods, who punished undue pride. In tragedy the moral lesson was to cultivate, a proper balance and awareness of one's true position" (Starr, 1980). It was to communicate such notions that the Greek dramatists have used their dramas and drama was the most comfortable mode of communication that could be utilized in order to attain this target during that ancient era.

The massive structures of Greek Theatres provided more than enough space for every citizen and as history unveils, the government has provided money for the poor citizens to participate in the festival. Well renowned theaters in Greece such as the theater of Epidaurus and the theatre of Dionysus were colossal theatre structures which have provided space for the audience from twenty thousand to thirty five thousand. For the Greeks these drama festivals were not held with the intention of financial gains, but they were a kind of religious festivals carried out in order to enhance the piety and devotion of the Greeks. 
The dramas were regarded as a mode of education for the adult citizens of the city as well and as Aristophanes, the comic writer mentions in his Drama Frogs that 'school boys have a master to teach them, grownups have the poets' (The Frogs, Aristophanes - Act II). He believed that the function of good poetry was to provide moral and political guidance to the lost citizens in order to create a real Athens and real Athenians, and in society the poets and the dramatists were considered important as they were accepted as the teachers of the adult citizens. At the same time they believed that Drama should be a mode of communication to the Athenians to arm them with patriotism towards their city against the barbaric invaders. Sikes (1931) questions, 'What was poetry 'for'? Was it to instruct or simply to please, or for both objects combined? As we shall see in detail, the Greeks were too moralistic a nation to divorce the poetic impulse from ethical values, even if there were some who revolted from the theory that the end of poetry is instruction, a theory natural enough when the poet (whatever else he might be) was certainly a teacher'.

\section{Conclusion}

During such an ancient period, there were no such modes like today to address the mentality of the common man of the society and this could be done only through drama which was the most intimate and reliable medium available for the dramatists. The dramatists were very successful in addressing the burning issues of the day and revolutionizing the attitudes of the common man through their literary masterpieces, philosophic concepts and dramatic characters. As the Greeks were a nation who were a part of a performance culture, drama was not a notion, the dramatists had to popularize among them with extra effort, because in their day- to-day life, this theatrical quality was embedded. Thus, there was no other medium which was close and effective like 'drama' to communicate to the mass of the Hellenic world.

From a macro perspective, it is possible to utilize drama as a mode of training employees to improve their job related knowledge, skills and attitudes for generic purpose of enhancing first, human performance and then organizational performance. Role Playing and Behaviour Modelling are training techniques and they involve basically dramas. A serious play for right management decision-making or generating right attitudes about organizational phenomena can be performed and also interest and excitement regarding various organizational phenomena can be created. Drama has the utility in training employees on interpersonal skills and cognitive skills presenting an ideal behaviour for solving a certain problem or dealing with a certain demand. Both participants in drama and observers can get benefited.

\section{References}

France, P. (1993), Greek as a Treat, Woodlands: BBC Books - A division of BBC Enterprises Limited.

Rehm, R. (1992), Greek Tragic Theatre, Cornwall: TJ Press (Padstow).

Sikes, E.E. (1931), The Greek View of Poetry, Hyperion Press.

Sommerstein, A.H. (2004), Greek Drama and Dramatists, Taylor and Francis e-library.

Starr, C.G. (1980), The Ancinet Greeks, Oxford: Oxford University Press.

Storey, I.C. and Allan, A. (1998), Guide to Ancinet Greek Drama, Blackwell Publishing. 